\title{
COMPARATIVE ACUTE TOXICITY OF CHLORPYRIFOS-ETHYL (Organophosphate) AND LAMBDA-CYHALOTHRIN (Pyrethroid) TO THE AFRICAN CATFISH (C.gariepinus) USING SOME BIOCHEMICAL PARAMETERS
}

O. E. OGUEJI

(Received 15, November 2007; Revision Accepted 16, April 2008)

\section{ABSTRACT}

The impact of short-term exposure to waterborne chlorpyrifos-ethyl and lambda-cyhalothrin on Clarias gariepinus was evaluated through changes of selected biochemical parameters. Fish was exposed to $0.64 \mathrm{mg} / \mathrm{l}, 0.80 \mathrm{mg} / \mathrm{l}, 0.96 \mathrm{mg} / \mathrm{l}, 1.12 \mathrm{mg} / \mathrm{l}$, $1.28 \mathrm{mg} / \mathrm{l}$ of chlorpyrifos-ethyl, and $0.008 \mathrm{mg} / \mathrm{l}, 0.009 \mathrm{mg} / \mathrm{l}, 0.010 \mathrm{mg} / \mathrm{l}, 0.011 \mathrm{mg} / \mathrm{l}, 0.012 \mathrm{mg} / \mathrm{l}$ of lambda-cyhalothrin and control for 96hrs. The $96-\mathrm{h} \mathrm{LC}_{50}$ value for C. gariepinus was estimated as $0.92 \mathrm{mg} / \mathrm{l}$ and $0.008 \mathrm{mg} / \mathrm{l}$ for chlorpyrifos-ethyl and lambdacyhalothrin respectively. The parameters measured were serum glucose, protein, cholesterol, triglyceride, glutamic pyruvic acid transaminase (GPT), glutamic oxaloacetic acid transaminase (GOT) and alkaline phosphatase (ALP).There was significant $(P<0.05)$ alterations between the control values and the exposed groups on all parameters. Chlorpyrifos-ethyl was more toxic to the fish than lambda-cyhalothrin.

KEYWORDS: Chlorpyrifos-ethyl, Lambda-cyhalothrin, biochemical parameters, Clarias gariepinus, acute toxicity.

\section{INTRODUCTION}

In the recent times in Africa, as a result of high population growth, accompanied by an intensive urbanization, an increase in industrial activities and a higher exploitation of cultivable land, there has been steady increase in the quantity and diversity of discharges that reach aquatic environment (West, 1988). Aquatic pollution by pesticides results mainly from their widespread use in agriculture and in vector control campaigns. In Nigeria especially in the northern part of the country, there is an upsurge in the application of pesticides in agriculture. A major reason for the increased use of pesticide in the north is the development of dry-season irrigated farming (Mbagwu and Ita, 1994). These poisons are washed into water bodies through surface run-off during the rainy seasons.

The application of pyrethroids as insecticides and antiparasitary preparations has very markedly increased. Thus pyrethroids are successively replacing organophosphate pesticides. The main advantages of pyrethroids are their photo-stability, high effectiveness in low concentrations, easy disintegration and low toxicity to birds and mammals (Maud et al, 1998). Fish are extremely susceptible to these substances. The $96-h \mathrm{LC}_{50}$ value, determined in laboratory tests generally lies below 10 $\mathrm{gg} / \mathrm{L}$ (Bradbury and Coast, 1989). In fish cultures, pyrethroids are applied to control some parasitic diseases caused by e.g. Lepeophtherius salmonis in farm cultures of salmonids (Toovey and Lydon, 2000). Direct and indirect contamination of aquatic environment by pesticides may cause fish kills, reduce fish productivity and elevate concentrations of undesirable chemicals in edible fish tissues. Pesticides can enter fish through their skin and gills during respiration and orally when feeding and due to the lipophilicity of pyrethroids, they have a high rate of gill absorption, which in turn would be a contributing factor in the sensitivity of fish to aqueous pyrethroid exposures (Rukiye et al., 2003). The mode of action of chlorpyrifos and their metabolites is inhibition of enzyme acetyl cholinesterase (AchE), and the inhibition of AchE activity caused by chlorpyrifos is more persistent than that caused by other organophosphates and it is believed that this is because chlorpyrifos is lipophilic (Chamber and Carr, 1993).

Africa's inland fisheries play a critical role in supporting the livelihoods and food security of millions of people across the continent. It generates employment and income for households and provides a major source of animal protein and essential micronutrient. Yet catches from most inland fisheries have reached their maximum capacity and many of them are considered to be over fished. Nigeria has abundant freshwater resources, with fish constituting about $40 \%$ of animal protein intake (Olatunde, 1989; Ita, 1993). Inland fisheries sub-sector contributes $86 \%$ of the domestic fish production, and about 0.3 million Nigerians engage in artisanal fish production. This means that any short fall in fish availability will reduce employment and animal protein intake of Nigerians especially those in the low income bracket.

Aquaculture production has increased from 100000 tonnes in 1994 to 520000 tonnes in 2003. The largest share of the output continues to be generated by Egypt ( 86 percent), followed by Nigeria (6 percent) and Madagascar ( 2 percent). Average yields in most countries remain low, commercial operators have yet to develop in many areas, and producers are few in number, with very little organization or capacity $(Y e$, 1999).

It should also be noted with some concern that some of the chemicals, e.g Organochlorines and organophosphates, which because of environmental considerations have been banned in some developed countries, are still being heavily used in Africa, and particularly in Nigeria. Multinational Corporations continue to market banned products in developing countries, making, profit their only motive (Pickering and Owen; 1994) Environmental laws and its managements have been weak especially in developing countries and have not stemmed the ever ragging pollution tide worldwide and more disturbing is the fact that less developed countries have even greater problems since government legislation and implementation is often crude due to poor resources (Pickering and Owen, 1994). Heckman (1982), reported that there is a death of information in the tropics about the adverse effects arising from the use of agricultural chemicals and that ecological relationships and productivity in tropical water bodies are often quite unlike those normally observed in the temperate zones.

Cells contain enzymes that are necessary to their function. When the integrity of a cell is disrupted, enzymes escape into plasma/serum, where their activity can be measured as a useful index of cell integrity (Coppo et al., 2002). Modifications in enzyme activity occur by cell death,

O. E. Ogueji, Department of Biology, Federal College of Education Katsina, P.M.B 2041, Katsina State, Nigeria 
increase or decrease enzyme production, obstruction of normal excretory route, increased cell membrane permeability, or impair circulation (Kaneko, 1989). Biochemical characteristics of blood are among the important indices of the status of internal environment of the fish organism (Edsall, 1999). Glutamate oxaloacetate (GOT) and glutamate pyruvate (GPT) transaminases are enzymes frequently used in the diagnosis of damage caused by pollutants in various tissues, such as liver, muscle and gills (de la Torre et al., 1999). Also alterations in the metabolism of protein and carbohydrate are used for similar purpose. Liver is the metabolic centre for detoxification of chemicals. Liver damage was confirmed by changes in the activities of glutamate- oxaloacetate transaminase (GOT) and glutamate - pyruvate transaminase (GPT) activities (Asztalos and Nemesok, 1985).

The objectives of this work include (1) Determine the relative toxicity of chlorpyrifos-ethyl and lambda-cyhalothrin to Clarias gariepinus. (2) Determine the relative sensitivity of Clarias gariepinus to chlorpyrifos-ethyl and lambda-cyhalothrin insecticides using biochemical parameters.

\section{MATERIALS AND METHODS}

Juveniles of Clarias gariepinus were purchased from Maigana fish farm in Zaria, Kaduna State Nigeria. The Clarias species averaging $14.33 \pm 0.50 \mathrm{~cm}$ standard length and body weight of $20.38 \pm 1.25 \mathrm{~g}$ were used for the study. The fish were conveyed to fisheries laboratory in a portable well-aerated white polythene bag containing water from the fish farm. They were held in large water baths of $160 \mathrm{~L}$ capacity at $24.5-25.5^{\circ} \mathrm{C}$ and acclimatized for two weeks in dechlorinated municipal water. During this period, the fishes were fed with pelleted diet containing $35 \%$ crude protein twice per day at $5 \%$ body weight. Also, the water in the glass aquaria was changed once every two days. The fishes were accepted as well as adapted to laboratory conditions when less than $5 \%$ death was recorded for the 14 days period and feeding was discontinued 24 hours before the start of the experimental run (Reish and Oshida, 1987).

\section{ACUTE BIOASSAY}

Acute 96-h static bioassays were conducted in the laboratory for the two chemicals following the methods of Sprague (1975) and APHA (1992). The nominal concentration for chlorpyrifos-ethyl was $0.64 \mathrm{mg} / \mathrm{L}, 0.80 \mathrm{mg} / \mathrm{L}, 0.96 \mathrm{mg} / \mathrm{L}$, $0.12 \mathrm{mg} / \mathrm{L}, 0.28 \mathrm{mg} / \mathrm{L}$ and the nominal concentration for lambda-cyhalothrin was $0.008 \mathrm{mg} / \mathrm{l}, 0.009 \mathrm{mg} / \mathrm{l}, 0.010 \mathrm{mg} / \mathrm{l}$, $0.011 \mathrm{mg} / \mathrm{l}$, and $0.012 \mathrm{mg} / \mathrm{l}$. The control had no toxicant. Each concentration was replicated three times. The desired chlorpyrifos and lambda-cyhalothrin concentrations were measured and introduced into 25L of dechlorinated tap water in the glass aquaria. The mixture was allowed to stand for 30 minutes before introducing test fishes. A total of 180 fish were stocked to give a loading rate of 10 fish per tank. Survival and mortality were recorded from 1to 6, 8, 16, 24, 72 and 96 hours. Fishes were considered dead when the opercular movement ceased and there was no response to gentle probing.

\section{BIOCHEMICAL MEASUREMENTS}

At the end of $96 \mathrm{hrs}$ exposure, the caudal peduncle of surviving fish was cut, blood was collected in non-heparinized tubes. The blood was immediately centrifuged at $1500 \mathrm{rpm}$ for $10 \mathrm{~min}$. Serum was then removed and stored at $4{ }^{0} \mathrm{C}$ prior to immediate determination of biochemical parameters, glucose, cholesterol, triglycerides, total protein, glutamic pyruvic acid trasaminase (GPT), glutamic oxaloacetic acid trasaminase (GOT) and alkaline phosphatase (ALP). Blood glucose was estimated using the method of Trinder (1969). Blood cholesterol was measured according to the procedure of Pearson et al (1953). Blood triglyceride was determined using the method of Rice (1970). The method of Lowry et al (1951) was carried out to determine the value of total protein. The activities of blood GPT and GOT were estimated according to the methods of Reitman and Frankel (1957). To determine the activity of blood ALP, Bassey et al (1946) method was used.

\section{STATISTICAL ANALYSIS}

Graph of probit kill against log concentration was used to determine the 96-h $\mathrm{LC}_{50}$. For the various biochemical parameters, the GenStat statistical analysis software(2006) was used to run analysis of variance (ANOVA) and Duncan multiple range test (DMRT) was used to test for differences between different levels of treatment and to separate means respectively, where applicable (Duncan, 1955). Test of significance was at the $5 \%$ level of significance.

\section{RESULTS}

Acute toxicity of the chemicals on C.gariepinus was carried out by static bioassay method, and the result revealed that the insecticides were highly toxic to C. gariepinus with 96$\mathrm{h} \mathrm{LC}_{50}$ value of $0.92 \mathrm{mg} / \mathrm{L}$ (Fig. 1) and NOEC estimated as $0.0092 \mathrm{mg} / \mathrm{L}$ for chlorpyrifos-ethyl. Similarly $96-\mathrm{h}$ LC $_{50}$ value of $0.008 \mathrm{mg} / \mathrm{L}$ (Fig. 2) and No Observed Effect Concentration (NOEC) of $0.8 \times 10^{-5} \mathrm{mg} / \mathrm{L}$ was obtained for lambda-cyhalothrin.

\section{Biochemical Parameters due to Acute Exposure of C.gariepinus to Chlorpyrifos-Ethyl}

Results of biochemical parameters of C. garipienus due to exposure of the fish to acute concentrations of chlorpyrifos-ethyl are presented in Fig. 3. For the exposed fish, significant $(P<0.05)$ dose dependent increases were observed in the blood glucose and protein levels. These parameters increased with increasing concentrations of exposure of the fish to the toxicant (Fig. 3). Dose dependent increase was also observed with GPT, increases in the parameter occurring with increasing concentrations of exposure, up to the $1.12 \mathrm{mg} / \mathrm{L}$ concentration where GPT level was a maximum. Beyond this concentration, however, GPT level dropped significantly $(P<0.05)$. A similar trend was observed with the blood cholesterol, with maximum cholesterol level obtained with the $0.96 \mathrm{mg} / \mathrm{L}$ concentration, beyond which significant $(P<0.05)$ decreases in blood cholesterol were observed (Fig. 3). GOT levels increased while ALP levels decreased significantly $(P<0.05)$ with increasing concentrations of chlorpyrifos-ethyl. Levels of triglycerides in the blood of the exposed fish rose with increasing concentrations of exposure in the $0.8-1.28 \mathrm{mg} / \mathrm{L}$ range. These values were lower than those of the control specimen. However, fish exposed to the $0.64 \mathrm{mg} / \mathrm{L}$ dose of chlorpyrifos-ethyl had significantly higher triglyceride levels than these, and than the control specimen.

\section{Biochemical Parameters due Acute Exposure of Fish to Lambda-Cyhalothrin}

Results of biochemical parameters of C. garipienus due to exposure of the fish to acute concentrations of lambdacyhalothrin are presented in Fig. 4. Significant $(P<0.05)$ dose dependent increases in glucose, cholesterol and triglyceride levels in the serum of the exposed fish were observed. The values of these parameters for the exposed fish were also significantly higher than those of the control specimen (Fig. 4). In contrast, there was a significant $(p<0.05)$ dose dependent decrease in GOT, GPT, ALP and protein in the exposed fish. The levels of these parameters decreased with increasing concentrations of lambda-cyhalothrin. GOT, GPT, ALP and protein levels recorded for the exposed fish were lower than those recorded for the control specimen. 


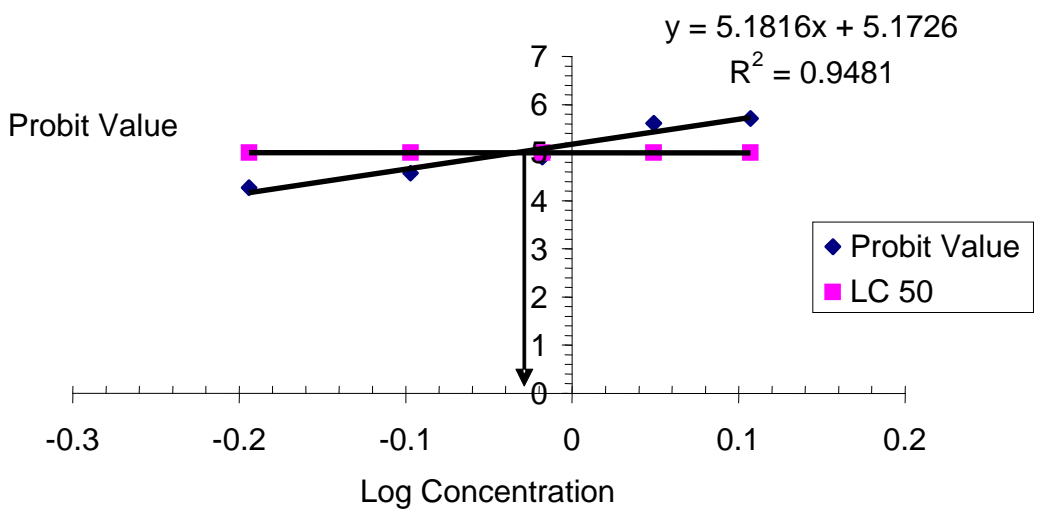

Fig 1: 96h LC50 of chlorpyrifos-ethyl for juveniles of Clarias gariepinus

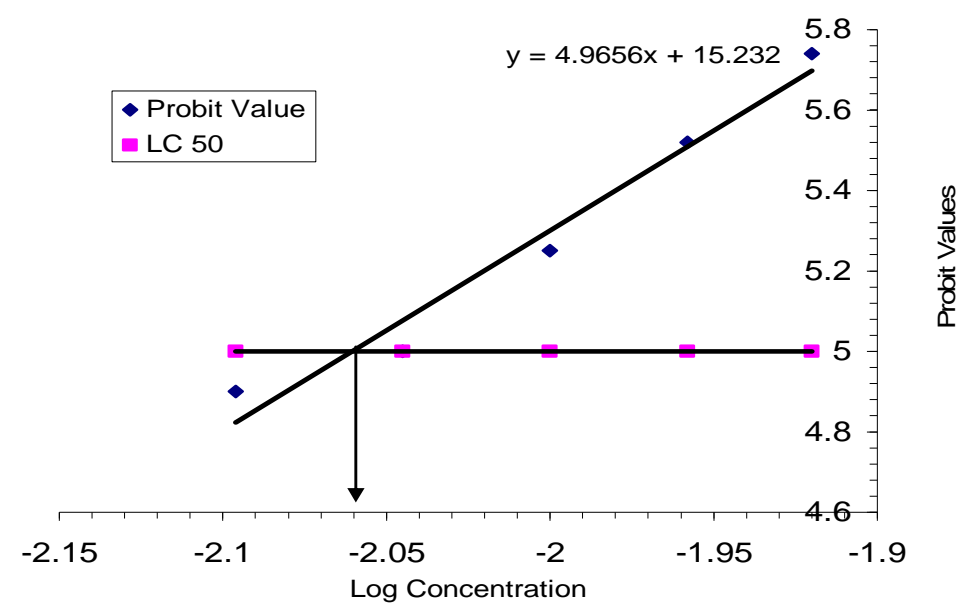

Fig 2: $96 \mathrm{~h} \mathrm{LC} 50$ of Lambda-cyhalothrin for juveniles of C. gariepinus

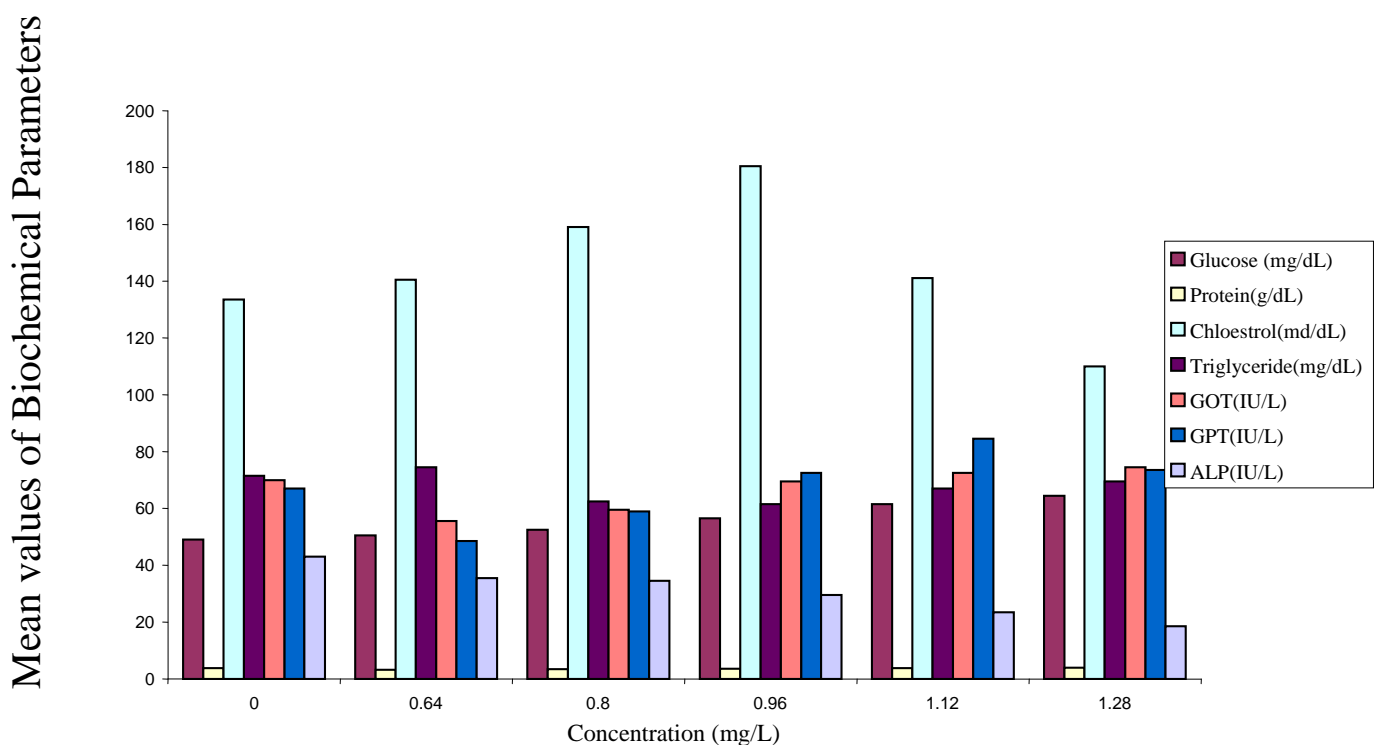

Fig 3:The effect of acute nominal doses of chlorpyrifos-ethyl on some biochemical parameters of C.gariepinus in 96hrs 


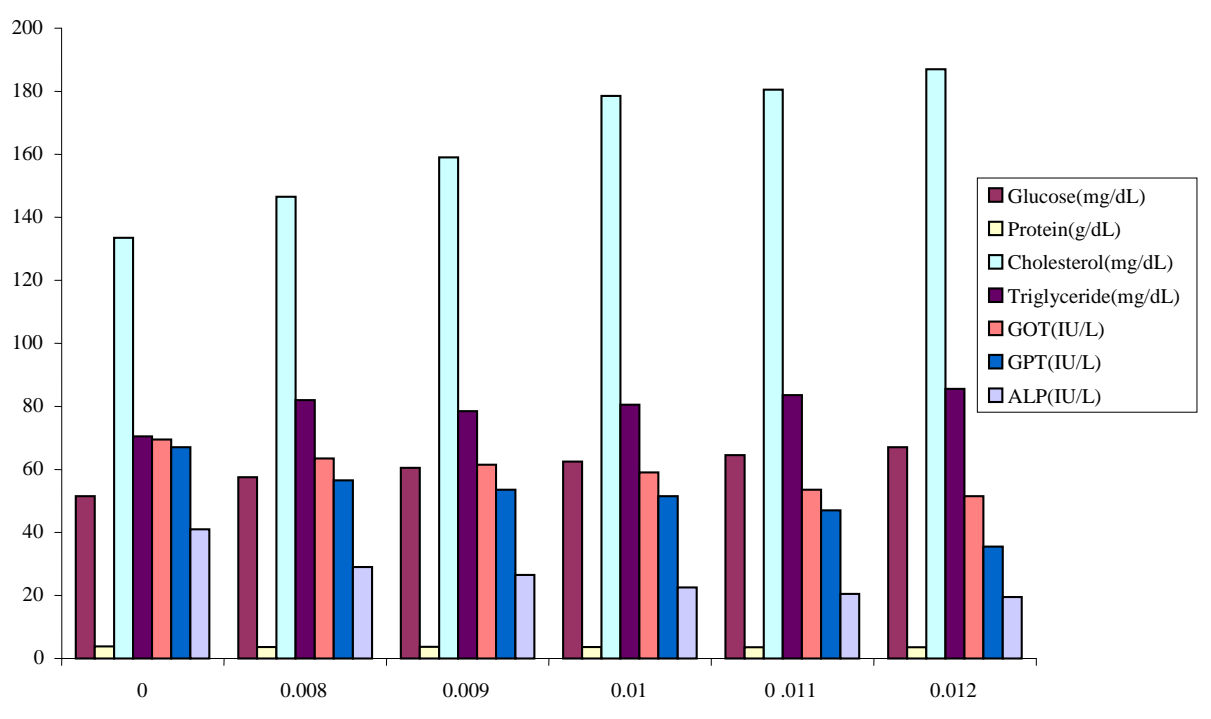

Fig. 4: The effect of acute nominal doses of lambda-cyhalothrin on some biochemical parameters of C.gariepinus in 96hrs

\section{DISCUSSION}

Changes on some Biochemical Parameters due Acute Exposure of fish to Chlorpyrifos-ethyl and Lambdacyhalothrin.

The 96-h LC50 value of $0.92 \mathrm{mg} / \mathrm{L}$ (Fig. 1) for chlorpyrifos-ethyl and $0.008 \mathrm{mg} / \mathrm{L}$ (Fig. 2) for lambdacyhalothrin shows that both chemicals are highly toxic to the fish. The lower 96-h $L_{50}$ value obtained for lambdacyhalothrin implies that it takes less acute concentration of the chemical to elicit toxic effect in the fish. These results were consistent with the findings of several other workers. Muller et al. (1978) reported static 48-h LC $_{50}$ of $0.005,0.006$ and 0.097 $\mathrm{mg} / \mathrm{L}$ for adult desert pupfish (Cyprinodon macularius), rainbow trout (Oncorhynchus mykiss) and western mosquito fish (Gambusia affinis) respectively.

The significant $(p<0.05)$ increase in glucose (hyperglycaemia) which was dose and duration dependent in the acute exposure to both chemicals may be considered to be manifestation of stress induced by the toxicants. The toxicants and their metabolites may have stimulated the adrenal tissue, resulting in increased level of circulating catecholaminies and glucocorticoids. These in turn stimulated the release of amino acids, glycerol and fatty acids, present in the blood and increased the synthesis of enzymes in the liver, which converted amino acids and glycerol into glucose (Gluconeogenesis). This was necessary to compensate for the high energy requirement needed for detoxification of the chemicals and fish survival in the toxic environment. This finding is in agreement with that of Hontela, et al, (1996), Luskova et al. (2002) and Atef (2005).

With the liver being the key organ in the synthesis and excretion of cholesterol, any type of obstruction in the liver either intra or extra hepatic, will cause an increase in total cholesterol levels on the serum. ANOVA result revealed that chlorpyrifos-ethyl elicited significant $(p<0.05)$ increase in the cholesterol values in the exposed group against control except in the highest nominal acute concentration. These results could possibly be correlated to the higher energy demands and impairments in the membrane organization induced by the toxicant in order to get the positive survival value under the imposed toxicant stress at the lower concentrations. However, in the highest nominal concentration, there may have been massive necrosis and probably cirrhosis of the liver which led to the inability of the liver to further synthesize cholesterol. The significant inhibition of cholesterol in the highest nominal concentration of chlorpyrifos-ethyl compared to elevation observed in similar concentrations of lambda-cyhalothrin implies that chlorpyrifos-ethyl elicited a more hazardous systemic/physiological impairment than lambda-cyhalothrin. Krishna et al (1994) also reported increased levels of phospholipids and cholesterol contents in the tissues of Tilapia mossambica subjected to acclimation in sub-lethal acidic water ( $\mathrm{pH}$ 4.0).

The significant inhibition of protein in the lower nominal concentrations of chlorpyrifos-ethyl may be due to protein deamination to give keto acids which are metabolized to produce caloric energy and also transformed into carbohydrates and lipids to compensate for the high energy requirement needed for survival in the toxic environment or high rate of protein degradation or impaired incorporation of amino acids into polypeptide chains. The observed significant $(p<0.05)$ hyperproteinamia in the highest acute concentration may possibly be due to water loss in the serum. Since there was dose dependent increase in total protein within the exposed group, the toxicant in the highest nominal concentrations may have induced liver necrosis, which led to impairment in the protein metabolism, resulting in the observed significant elevations in its concentrations. In the exposed group to lambda-cyhalothrin, the decrease in protein was dose-dependent from the lowest acute concentration $(0.008 \mathrm{mg} / \mathrm{L})$ to the highest $(0.012 \mathrm{mg} / \mathrm{L})$. This comparative toxicological difference especially at the highest acute concentrations of both chemicals showed that the degree of necrosis and or apoptosis elicited by chlorpyrifos-ethyl was more than that of lambda-cyhalothrin. Although study on protein deamination was not carried out, some authors have observed and reported elevations and inhibitions of protein levels. Sahib et al (1984) observed that the protein content in all tissues of malathion exposed Tilapia mossambica is slightly higher. Bradbury et al (1987), pointed out that the decreased protein content might also be attributed to the destruction or necrosis of cells and consequent impairment in protein synthesis machinery. Gill et al (1991) found an increase in liver proteins following Endosulphan intoxication and noted that protein levels in the liver of Barbus conchonious could be due to increased protein turnover. They also concluded that 
compensatory production of enzymes lost as a result of tissue necrosis or to meet increased demand to detoxify the pesticides might have necessitated enhanced synthesis of enzyme proteins (Gill et al, 1991). Several drugs have been known to decrease serum protein levels in humans, e.g Rifampin (Rifamylin) reduces serum protein by impairing protein synthesis; Trimethadione decreases protein levels by urinary loss and long-term use of laxatives results in fecal malabsorption and thus decreases serum protein levels (Gregor and John, 1995).

The principal function of triglycerides in biochemical systems is the storage of energy. If more energy-rich nutrients are consumed than are required for metabolic processes, much of the excess is converted to neutral glycerides and stored as triglycerides in fat cells of adipose tissue. When energy is needed, the triglycerides are metabolized by the body, and energy is released (Katherine et al., 2004). Elevation observed in chlorpyrifos-ethyl exposed fish especially in the lower acute concentration, may be due to impairments in the cell membrane organization and higher energy demands of $C$. gariepinus to get the positive survival value under the imposed acute toxicant stress leading to increased synthesis. The inhibitions in the exposed groups $(0.80 \mathrm{mg} / \mathrm{L}-1.12 \mathrm{mg} / \mathrm{L})$ may be associated with increased metabolism, due to higher demand for energy as concentration of toxicant increases. In the highest acute concentration of $1.28 \mathrm{mg} / \mathrm{L}$, triglyceride approached control values. This was due to induced liver necrosis or apoptosis which may have affected the ability of the liver to synthesize triglyceride and or slowed metabolism of triglyceride, since liver is the principal center of lipid metabolism. The behaviour of triglyceride in lambda-cyhalothrin exposed fish, showed similar pattern, except that there was a significant dose-dependent increase in the values of triglyceride from $0.010 \mathrm{mg} / \mathrm{L}$ to the highest acute concentration of $0.012 \mathrm{mg} / \mathrm{L}$. This implies that the degree of necrosis and or apoptosis in the highest acute concentration of lambda-cyhalothrin exposed fish was less compared to chlorpyrifos-ethyl exposed fish. Triglyceride accumulation occurs in fatty liver due to effect of toxicants. The accumulation occurs as a result of an imbalance between the rate of synthesis and the rate of release of triglyceride by the parenchymal cells into the systemic circulation (Gabriel, 1986). Izaguirre et al. (2000) observed cypermethrin-induced apoptosis (a programmed cell death) in the telencephalon of Physalaaemus biligonigerus tadpoles, and opined that it was mediated by reactive oxygen species (ROS) and lipid hydroperoxide radicals.

There was also significant $(p<0.05)$ inhibition in ALP as acute concentration increased, suggesting that more energy was needed at higher nominal concentrations to achieve the positive survival value. ALP is mainly localized at the cell membrane. Any damage in hepatic cells may result in alteration in ALP activity. The dose-dependent inhibitions observed in this investigation of the two chemicals may also be due to liver dysfunction. This observation is in agreement with the report of many other authors. Sastry and Sharma (1980) reported ALP inhibition after 96h exposure to diazinon.

The observed significant $(p<0.001)$ elevation of GOT and GPT at the higher nominal concentrations of the toxicant, showed firstly that there was a faster metabolic activity induced by the toxicant in the exposed group at the higher concentrations, and this may be attributed to the induction of hepatic microsomal cytochrome $\mathrm{P}_{450}$ dependent monooxygenase pathway. The increased metabolism of chlorpyrifos-ethyl, led to increased formation of the metabolite chlorpyrifos-oxon, which was several times more toxic to the nervous system of the fish and also inhibits the activity of detoxifying enzymes. And since there was a dose dependent significant $(p<0.05)$ increase in the values of the enzymes in the exposed group, it means that the antioxidant defenses of the fish was progressively weakened as the concentration increased, leading to lipid peroxidation and oxidative stress.
The lipid peroxidation progressively led to decreased membrane fluidity, increasing leakiness of membrane. The significant inhibition $(p<0.05)$ of GPT in the highest concentration of chlorpyrifos-ethyl, and also similar inhibition of GOT and GPT in the highest concentration of lambdacyhalothrin among the exposed group may be due to hepatic impairment in the mobilization of the enzymes, caused by cell death (necrosis or apoptosis or both). Deltamethrin have also been reported to be inhibitory to the monooxygenase system of carp liver (Cyprinus carpio L.) at higher concentrations of $2 \mu \mathrm{g} / \mathrm{l}$. The low concentration of $0.2 \mu \mathrm{g} / \mathrm{l}$ resulted in faster metabolism and was evaluated as induction of hepatic microsomal cytochrome $\mathrm{P}_{450}$ - dependent monooxygenase (Deer et al, 1996).

Recent evidence suggests that waterborne contaminants which generate reactive oxygen species (ROS) may be a significant source of toxicity for aquatic organisms living in polluted environments and may be partially responsible for disruptions in physiological function (Livingstone, 2001 ). In addition, it has been reported that organophosphates are reactive and may cause direct oxidative damage to membranes (Galloway and Randy, 2003). Khurshid (2003) opined that toxic effects of cypermethrin on chick embryo at higher doses and no effect at lower doses of the toxicant indicated that cypermethrin was metabolized to its toxic metabolites, which at lower doses can be detoxified by conjugating with glutathione, but at higher doses are unable to be detoxified as the glutathione level in the tissue depletes. Oakes et al. (2004) argued that excessive ROS production in response to xenobiotics inducing compounds can overwhelm endogenous detoxifying mechanisms producing the cumulative damage to cellular constituent's termed oxidative stress.

Sadhu et al (1985) have decreased GOT and GPT activities in the serum of Channa striatus following exposure to $0.1 \mathrm{ppm}$ malathion for 10days. Similarly, Asztalos et al (1988) have reported elevation in serum GOT activity of Cyprinus carpio which have hepatic cellular damage caused by methidation + paraquat. Conversely, Oruc and Uner (1999), reported inhibition in seral GPT and GOT enzyme activity following 2 and 30days of exposure to 2, 4-Diamin. GOT and GPT are important in the diagnosis of heart and liver damage (Dere and Polat, 2001).

\section{CONCLUSION}

Synthetic pyrethroids (lambda-cyhalothrin) and organophosphates (chlorpyrifos-ethyl) are widely used in agriculture in Nigeria. They are increasingly being used in veterinary applications on farm and pet animals, for the protection of stored foodstuffs, for the control of endemics and parasites in public health programmes as well as for household applications in kitchens and bedrooms. Acute exposures of aquatic biota and individuals may result through run-off and adsorption of the insecticides to small dust particles and various other surfaces respectively. The results of this study suggest that acute exposure of $C$. gariepinus to the two chemicals elicited similar toxic responses in some of the biochemical parameters e.g Glucose and ALP. However, in protein, cholesterol, triglyceride, GOT and GPT, there were differences in comparative toxicity effects of the two chemicals. Chlorpyrifos-ethyl induced more systemic/physiological damage to the fish than lambda-cyhalothrin. Both chemicals led to alterations in carbohydrate and lipid metabolism and possible organ damage. Further studies on histopathology and antioxidant mechanisms of this fish exposed to the pesticides need to be carried out to authenticate the current work.

Water quality criteria for various species of fish have not received adequate attention that it deserves. Degradation in the aquatic habitat through pollution, and decrease in annual production and subsequent harvest of fish, has often passed unnoted (Calamari and Naeve, 1994). In the light of the above observations, it is recommended that Federal Ministry of 
Environment, should classify pesticides according to their chemical nature, and researches should be encouraged to generate more information on the acute toxicities and No observed effect concentrations (NOEC's) for our numerous freshwater fish species. Such information will go a long way to helping in the control and use of numerous classes of pesticides that have flooded the Nigerian market.

\section{REFERENCES}

American Public Health Association (APHA), American Water Works Association (AWWA) and Water Environment Federation (WEF), 1992. Standard Methods for the examination of Water and Wastewater , $18^{\text {th }}$ Edition; Washington, D.C .

Atef, M. M., 2005. Biochemical Effects of short-term Cadmium Exposure on the fresh water fish. Oreochromis niloticus. Jour. of Bio. Sc. 5(3): 260-265.

Asztalos, B. and Nemcsok, J., 1985. Effects of pesticides on the LDH activity and isoenzyme pattern of Carp (Cyprinus carpio) sera. Comparative Biochemistry and Physiology, 82: 217-219.

Bassey, O.A. Lowery, O.H. and Brock, M. J., 1946. A method for the rapid determination of alkaline phosphatase with $5 \mathrm{~mm}^{3}$ of serum. J. Biol. Chem; 164-: 321-329.

Bradbury, S.P., Symonic, D.M., Coats, J.R. and Atchison, G.

J., 1987. Toxicology of fenvalerete and its constituent's isomers to the fathead minnow (Pimephales promelos) and blue gill (Lepomis macrochirus). Bulletin of Environmental Contamination and Toxicology. 38: 727-735.

Bradbury, S. P. and Coast, J. R., 1989. Toxicokinetics and Toxicodyamics of pyrethroid insecticides in fish. Environmental Toxicology and Chemistry, 8:373 380.

Calamari, D. and Naeve, H., 1994. Review of Pollution in the African aquatic environment. CIFA Technical Paper No 25 FAO Rome.

Chambers, J. E. and Carr, R. L., 1993. Inhibition patterns of brain acetylcholisnesterase, hepatic and plasma aliesterases following exposures to three phosphorothionate insecticides and their oxons in rats. Fund. Appl. Toxicol. 21:111-119.

Coppo, J. A., Mussart, N. B. and Fioranelli, S. A., 2002. Physiological variation of enzymatic activities in blood of Bullfrog, Rana catesbeina (Shaw, 1802). Reviews: Veterinary Embryology, 12/13: 22-27

De la Torre, F.R., Salibian, A. and Ferrari, L., 1999. Enzyme activities as biomakers of freshwater pollution: responses of fish branchial $\left(\mathrm{Na}^{+} \mathrm{K}\right)$-ATPase and liver Transaminases. Environmental Toxicology. 14:313319.

Deer, A. K. Banka, L., Nemcsok., J. and Abraham, M., 1996. Effects of deltamethrin on hepatic microsomal cytochrome $\mathrm{P}_{450}$ - dependent monooxygenase in Carp. Journal of Environmental Science and Health, 31(3): 637-644.

Dere, E. and Polat, F., 2001. The effect of paraquate on the activity of some enzymes in different tissues of mice (Mus musculus). Turkey Journal of Biology. 25:323332.

Duncan, D. B., 1955. Multiple range tests. Biometric, 11: 1-42.
Edsall, C.C., 1999. A blood chemistry profile for lake trout. Journal of Aquatic. Animal Health, 11: 81-86.

Gabriel L. P., 1986. Toxicology of the liver. In Casarett and Doulls Toxicology; The basic science of poisons $3^{\text {rd }}$ ed. Macmillan publishing Co. New York.

Galloway, T. R. and Randy., 2003. Immunotoxicity of organophosphorous pesticides. Ecotoxicicology 12:345-363.

GenStat-Release 4.2 2006. Discovery Edition, VSNInternational Ltd, Lawes Agricultural Trust. www.worldforestrycenter.org/genstatforafrica

George, G. and Nagel, R., 1990. Toxicity of Lindane, Atrazine and Deltamethrin to early life stages of zebrafish (Bradydario rerio). Exotoxicol. Environ. Saf. 20: 246255.

Gill, T.S., Tewari, H., Pande, J., 1991. In vivo and in vitro effects of cadmium on selected enzymes in different organs of the fish Barbus conchonius Ham. (Rosy barb). Comp. Biochem. Physiol. 100: 501-505.

Gregor, H. G. and John, F. K., 1995. Plasma and serum proteins In: Fundamentals of Clinical Chemistry. Eds. Norbert, W.T. Saunders, London. Pp: 377-389.

Heckman, W. C., 1982. Pesticide effects on aquatic habitats. Environ. Sci. Technol. 16:48-57.

Hontela, A., Daniel, C. and Ricard, A. C., 1996. Effect of acute and sublethal exposure to Cadmium on the interregnal and thyroid function in rainbow trout, Oncorhyncus mykiss. Aquatic Toxicology. 35: 171182.

Ita, E. O., 1993. Inland Fisheries Resource of Nigeria. CIFA Occassional Paper No 20. Rome, FAO 88-90.

Izaguirre, M.F., Lajmanovich, R.C., Peltzer, P.M., Solar, A.P. and Casco, V. H., 2000. Cypermethrin-induced apoptosis in the telencephalon of Physalaemus biligonigerus tadpoles (Anura: Leptodactylidae). Bull. Environ. Contam. Toxicol, 65: 501-7.

Kaneko, J. J., 1989. Clinical Biochemistry of Domestic Animals, $4^{\text {th }} \mathrm{Ed}$, Academic Press, San Diego, 823pp.

Katherine, J. D., Joseph, J. P. and Robert, L. C., 2004.General Organic and Biochemistry. Fouth Ed. McGraw-Hill New York, pp.536-545.

Khurshid, A., 2003. Cypermethrin, A pyrethroid Insecticides induces Teratological and Biochemical changes in young chick embryos. Pakistan J. of Bio. SC. 6 (19):1698-1705.

Krishna, M. V., Bhaskar, M., Govindappa, S., 1994. Studies on lipid profiles of fish liver on acclimation to acidic medium. J. Environ. Bio. 15(4):269-273.

Livingstone, D., 2001. Contaminant-stimulated reactive oxygen species production and oxidative damage in aquatic organisms. Mar. Pollut. Bull. 42: 656-666.

Lowry, O. H., Resebrough, N. J., Farr, A. L. and Randall, R. J., 1951. Protein measurements with Folin phenol reagent. Journal of Biology and Chemistry, 193:265-275

Luskova, V., Svoboda, M. and Kolarova, J., 2002. The effects of Diazinon on Blood Plasma Biochemistry in Carp (Cyprinus carpio L.) Acta Veterinaria Brno, 71:117123. 
Maud, S. J. Hamer, J., Wariton, J. S., 1998. Aquatic ecotoxicology of the pyrethroid insecticide Lambdacyhalothrin: consideration for higher tier aquatic risk assessment. Pestic Sci. 54:408-417.

Mbagwu, I. G. and Ita, E. O., 1994. Pesticide use in the subhumid zones of Nigeria: Implication for conservation of Aquatic Resources. Environmental Conservation, 21(3): 214-219.

Muller, M. S., Navab-Gojrati, H. A. and Darwazeh, J. A., 1978. Toxiciy of mosquito larvicidal pyrethroids to four species of freshwater fishes. Environmental. Entomology 7: 428-430.

Oakes, D. K., Mark, E. M. and Glen, J. V., 2004. Oxidative stress responses in long nose sucker (Catostomus catostomus) exposed to pulp and paper mill and municipal sewage effluents. Aquatic Toxicology, 67: 255-271.

Olatunde, A. A., 1989. Approaches to the study of fisheries Biology in Nigerian Inland Waters. Proceedings of National Conference of two decades of research on Lake Kainji (Ayeni and Olatunde [Eds]) pp.538-541.

Oruc . E. O. and Uner. N., 1999. Effects of 2, 4-Diamin on some parameters of protein and carbohydrate metabolisms in the serum, muscle and liver of Cyprinus carpio. Environmental Pollution, 105: 267272.

Pearson, S., Stern, S. and Mogavack, T. H., 1953. A rapid procedure for the determination of serum cholesterol. J.clin. Endocrinol. pp. 666

Pickering, K. T. and Owen, L. A., 1994. An Introduction to Global Environmental issues. Rutledge, U.S.A.pp:345-400.

Reish, D. L. and Oshida, P. S., 1987. Manual of methods in aquatic environment research Part 10. Short term static bioassay. FAO. fisheries. Technical paper 247, FAO Rome pp 1- 62.

Reitman, S. and Frankel, F., 1957. A colorimetric method for determination of serum glutamic oxaloacetic and glutamic pyruvic acid transaminase. American Journal of Clinical Pathology, 28: 56-60.
Rice, E., 1970. Triglycerides (Natural fats) in serum. Stand. Meth. Clin. Chem. Academic Press, New York, pp: 215.

Rukiye , V., Figen U. E., Hilal, P. and Oner, K., 2003. Investigation of acute toxicity of deltamethrin on guppies (Poecilia reticularta) Ecotoxicology and environmental safety, 55: 82-85.

Sadhu, K. A., Chowdhury, D. K. and Mukhopadhyay, P. K., 1985. Relationship between serum enzymes, histological features and enzymes in hepatopancreas after sub lethal exposure to malathion and phophamidon in the murrel Channon striatus (B.L.). Journal of International and Environmental Studies, 24: 35-41.

Sahib, I. K. A., Sambasiva Rao, K. R. S. and Ramana Rao, K. V., 1984. Effect of malathion on protein synthetic potentiality of the tissues of the teleost, Tilapia mossambica (Peters), as measured through incorporation of $\left[{ }^{14} \mathrm{C}\right]$ amino acids. Toxicology Letters, 20: 63-67

Sasty, K. V. and Sharma, K., 1980. Diazinon effect on the activities of brain enzymes from Opicephalus princtatus (Channa). Bull. Environ. Contam. Toxicol. 24: 326-332.

Sprague, J. B., 1975. Measurement of pollution toxicity to fish: In Bioassay methods for acute toxicity. Water Research, 3: 346-349.

Toovey, J. P. G. and Lyndon, A. R., 2000. Effects Of hydrogen peroxide, dichlorvos and Cypermethrin on subsequent fecundity of sealice, lepeophithenus salmonis, under fish farm conditions. Bull. Env. Ass. Fish Pathol, 20:224-228.

Trinder, P., 1969. Determination of bood glucose using 4aminophenazone. J. Clin. Patho, 22:246.

West, W. Q. B., 1988. African Inland Water Fisheries and the Environment. Proceeding of the National Conference on two Decades of Research on Lake Kainji.29 ${ }^{\text {th }}$ Nov$1^{\text {st }}$ Dec 1989. NIFFR

Ye, Y., 1999. Historical consumption and future demand for fish and fishery products: Exploratory calculations for the years 2015-2030. FAO Fisheries Circular No. 946, Rome, 